\title{
Using the Balanced Scorecard in Private Sector Organizations: A Case Study of Private Telecommunication Companies in Sudan
}

\author{
Gaafar Mohamed Abdalkrim ${ }^{1}$ \\ ${ }^{1}$ Department of Business Administration, College of Science and Humanity Studies-Alsulial, Salman Bin \\ Abdulaziz University, Kingdom of Saudi Arabia \\ Correspondence: Gaafar Mohamed Abdalkrim, Department of Business Administration, College of Science and \\ Humanity Studies-Alsulial, Salman Bin Abdulaziz University, P. O. Box 339, Alsulail 11913, Kingdom of Saudi \\ Arabia. Tel: 966-555-240-760. E-mail: gaafarabdalkrim@gmail.com
}

Received: June 30, 2014

Accepted: August 4, 2014

Online Published: August 25, 2014

doi:10.5539/ibr.v7n9p157

URL: http://dx.doi.org/10.5539/ibr.v7n9p157

\begin{abstract}
The improvement of organizations and employee performance is ongoing journey. Previous studies and official document of managerial practices have confirmed that the balanced scorecard (BSC) is one of the latest innovations in management assist organizations to rationalize vision and strategy with business activities and measure a real organizational performance versus predetermined goals. The balanced scorecard also is applied to measure financial processes, customer relation, internal business processes and learning \& growth characters of the organization. The main aims of this research is to identify the role of balanced scorecard (BSC) represent in better performance of organizations and to shed light on the impacts of balanced scorecard on organizational performance. The research has been performed with quantitive method and the organizations in questions are Telecommunication companies in Sudan for the purpose, the research supported by a questionnaire identifies that balanced scorecard is well implemented in the private sector organization in Sudan. Furthermore, currently there is lack of published research on BSC within private sector, so it has motivated me to highlight gaps in this research and to outline some ideas for future research. The findings indicate that positive relationship exists between the four perspectives in the BCS model and organization performance in Sudanese private sector companies.
\end{abstract}

Keywords: Balanced Scorecard, performance, private sector organizations, telecommunication companies

\section{Introduction}

Rapidly change and hyper- competitive environment in the global business landscape in recent decades have forced the companies to improve their performance to emerge as competitive global player and to select an appropriate and effective performance to help management assess strategic plans and minimize errors. Performance measurement is putting a figure on the competence and effectiveness of former action through the procuration, collection, categorization, analysis and interpretation of suitable data (Ayesha, F. \& Zareen, H., 2011). Robert Kaplan and David Norton wrote about balanced scorecard in 1992 as a rendering measurement skeleton that added strategic non- financial performance measures to traditional financial metrics in order to give managers a more "balanced" sight of organizational performance. 2014 marks 22 years since the first publication of BSC Kaplan and Norton's original version of BSC disseminated on mere financial performance measure and incorporated operation performance classified by three perspectives: customer satisfaction, internal business process, and innovation and learning. Since Norton and Kaplan comprised a chain of articles (Kaplan \& Norton, 1993; Kaplan, 2009; Kaplan \& Norton, 2000) and a lot of books to advanced knowledge base on the balance scorecard. In general, a BSC system is considered to be a performance measurement, strategy evaluation system, and a communication tool at the same time.

\section{Conceptual Foundation of Balanced Scorecard}

Considering the specific application of BSC, this part review the literature relate to general Balanced scorecard frame work as introduced by Kaplan and Norton, the original perspective of BSC, (as shown in figure 1) the effectiveness of BSC. BSC is initially devised by Kaplan \& Norton as the multi- dimension performance measurement system with a connection of monetary and non financial measure and it's now transformed into a strategic performance measurement system. It was also promoted as a communication and strategy alignment 
tool. It gives the need for organization to manage all its resources and due to increasing amount of competition in the information and technology society. The BSC rapidly developed in recognition of its potential and emerged as a new strategic management system (Butler et al, 1997). For BSC incorporated various important attributes. Translating strategy into operation item, aligning the organization units to the strategy, communicating strategy to employee and providing feedback and learning (Wasaton Chutibhinyo, 2012). BSC as Kaplan and Norton stated propose an answer to the following four questions: (Fawzi et al., 2011).

1) How do customers see us?

2) What must excel at?

3) Can we continue to improve and create value?

4) How do we look to shareholder?

The idea of the balanced scorecard is specify in an article that Kaplan wrote in 1992 for Harvard Business Review, along with David Norton, the president of a consulting firm called Renaissance Strategy Group. The article, entitled "The Balanced Scorecard Measures that Drive Performance", began with the idea that what things you can measure is what things you can get. They saw some of the advantages of the balanced scorecard as follows:

1) It lends a hand to companies to spotlight on what needs to be done so as to create a "breakthrough performance".

2) It operates as combining tool for diversity often disconnected corporate programmes, such as quality, re-engineering, process redesign and customer service.

3) It transforms strategy into performance measures and goals.

4) It helps break down corporate-wide measures so that local managers and employees can see what they need to do to improve organizational effectiveness.

5) Inflection inclusive view that overturns the traditional idea of the organization as a collection of isolated, independent functions and departments.

The fathers of BSC announced that non-financial measure in addition to financial measure must be used to decide and to manage. In 1996 they associated balanced scorecard to organization's strategies, they made four perspectives linked with each other to explain the strategic objectives to tangible objectives and measures. These steps: illustrating and translating vision and strategy, communicating and connecting strategic objectives and measure, business planning and target setting and enhancing strategic feedback and learning. In 2001 they stated five basic philosophies to keep strategy the focal point of organization's management process. These principles are: translating the strategy into operational terms, align the organization to the strategy, make strategy everyone's everyday job, make strategy a continual process, and mobilize change through executive leadership. After these processes balanced scorecard becomes not only a collection of financial and non-financial measurement but also translator of business unit's strategy into a linked set of measures that define both the long-term strategic aim as well as the mechanisms for reaching those purposes. 


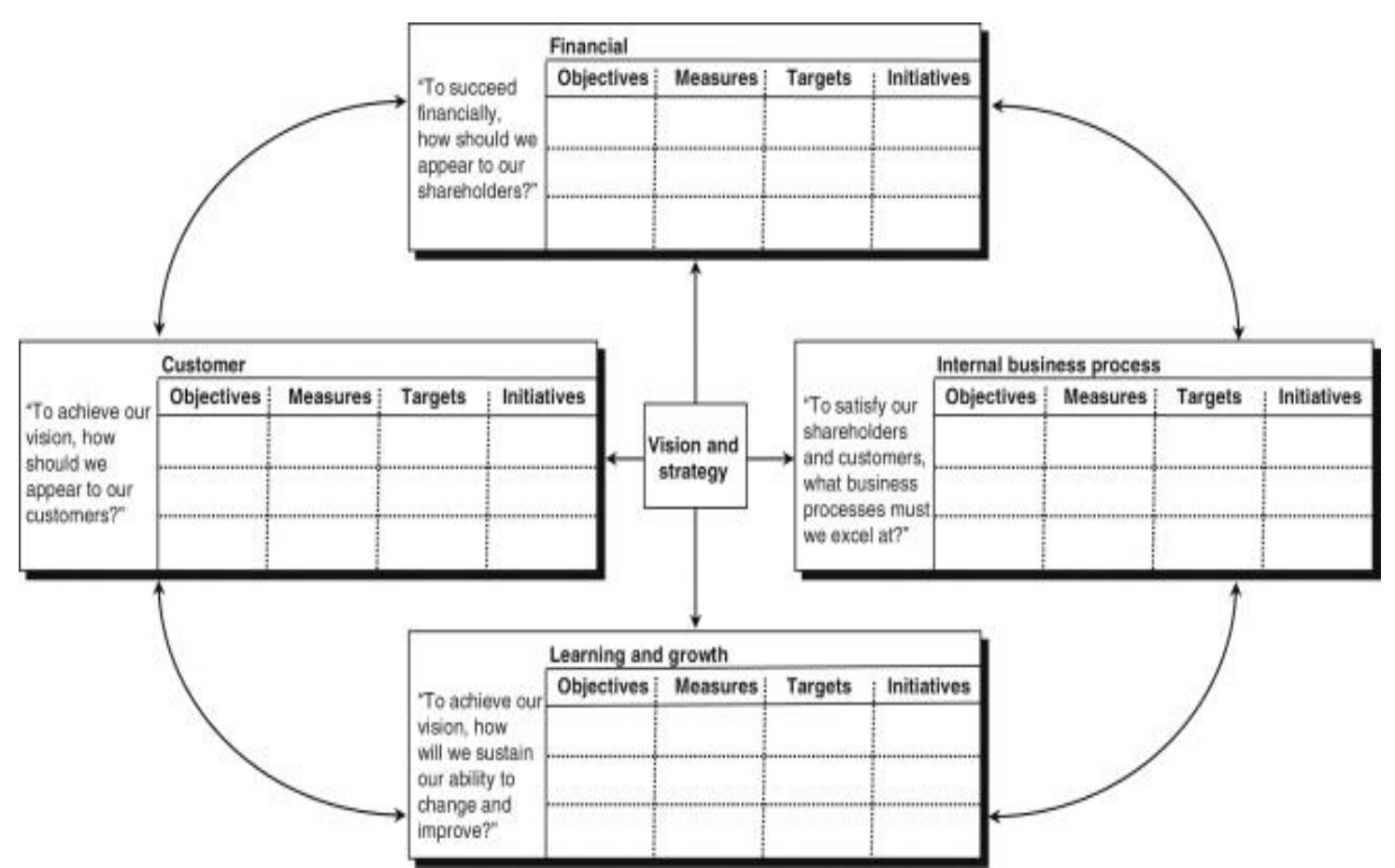

Figure 1. BSC perspective (Robert S. Kaplan, 2008)

\subsection{The Balanced Scorecard Perspective}

Kaplan and Norton the earliest balanced scorecard diagram acknowledged the following four perspectives: the financial perspective, the customer perspective, the internal business- process perspective and the learning and growth perspective. These balanced scorecard perspectives signify three major stakeholder of any corporation (shareholder, customers and employee), (Kiran Jude, et al, 2006). Every one of these perspectives contain the general principle (what do we want to achieve?), measures (how do we measure?) and aims (realization of principles).

\subsubsection{Financial Perspective}

Financial perspective becomes aware of how the business wishes to be sighted by its share holder (NØrreklit, 2000). It has been noted that the traditional technique of evaluating managerial success and influence but the desires for financial measure is still tremendously strong element to establish success (Niven, 2002). It essentially consist of those measure coping with corporation profitability, (Maltz et al., 2003) recommended the following measures: profit margin, revenue growth, cash flow, net operating income, retune on investment(ROI), revenue per employee, profit per employee, stock price, economic value added (EVA), earning per share (EPS), retune on equality (ROE), and growth in common equality. But these measures are vary from one firm to another and that mean there is no a clear criterion set of financial measure which could be apply across different contextual organizational framework and environment.

\subsubsection{Customer Perspective}

In modern management philosophy there is an increasing realization of the importance of customer focus and customer satisfaction. customer perspective stand for the relationship between an organization and its customer it is an important perspective in helping an organization to improve their financial result also, it define how firms differentiates itself from competitors to attract retain and deepen relationship with targeted customers ( Kaplan \& Norton, 2001). Measures for customer perspective address factors that relate to customer satisfaction, such as: customer retention, market share, lead time, defects and customer complains (Inaam, 2012).

\subsubsection{Learning and Growth Perspective}

It aims to identify professions (human capital), system (information capital), and organization state (organization capital). (Ali et al., 2011) those sources represent the roads that any company must construct so as to create and maintain long- term growth and improvement because rigorous global competition requires that firms frequently improve and advance their capability for delivering value to customers and share holders by increasing 
investment in these three mentioned sources. Measures for this perspective deal with factors such as member of staff skills, firm leadership, organizational learning, hours of employee training, and employee satisfaction.

\subsubsection{Internal Business Process Perspective}

Internal business process perspective spotlight on the technique and procedure used inside the organization produced and drive product. It identifies key operational processes in which the organization must excel. It is interesting to note that according to fathers of BSC the market must not be overlooked "internal measures to BSC should be drived from those business processes that have the largest impact on customer"(Carlotta et al., 2012).

\section{The Objectives of the Study}

The balanced scorecard turns out to be an essential management equipment for the assessment of effectiveness of whole organization. This merely because the BSC describe not only an organization's existing performance but also a driver for its coming years performance so many organizations have implemented the balanced scorecard (BSC) to measure performance and monitor strategy (Willian \& Paul, 2005). The main aim of this study is to recognize the influence of applying the balanced scorecard methodologies on organizational performance, so we stared those following objectives.

1) To identify challenges in implementing the BSC on Telecommunication companies in Sudan as one of developing countries.

2) To study the concept of BSC. And to create an increasing awareness in organization regarding effective balanced scorecard.

3) Contribute to the future development and provide a basis for future research in Sudan and other developing countries.

\section{Importance of the Study}

This study stems its importance from the following reasons:

1) The study will break new ground in balanced scorecard field especially for private sector telecommunication companies in Sudan as there is scarcity of research in this field.

2) It examines the use and implementation of balanced scorecard in telecommunication companies.

3) The findings of this study will be valuable for other private firms that wish to use the balanced scorecard model to measure their performance, and to create a better understanding for balanced scorecard.

4) The outcome of the study will be valuable for academicians; they can gain insights and ideas for future research.

\section{Research Hypotheses}

So as to reach the objectives intended for this study, the subsequent research hypotheses are stated based on the revelation in the review of literature relating to the balanced scorecard and organizational performance.

- A considerable positive relationship exists between financial perspective in the BCS model and organization performance in Sudanese private telecommunication companies.

* A considerable positive relationship exists between customer perspective in the BCS model and organization performance in Sudanese private telecommunication companies

* A considerable positive relationship exists between internal processes perspective in the BCS model and organization performance in Sudanese private telecommunication companies.

* A considerable positive relationship exists between learning \& growth and organization performance in Sudanese private telecommunication companies.

\section{Research methodology}

\subsection{Sample}

The research population is the group of people, organizations, or any other collection of substance under consideration for a research purpose (Jehad, 2011). The population of this research is made-up of all telecommunication organizations in Sudan, the study covered the capital of the country .The respondents were managers of telecommunication organizations. 


\subsection{Data Collection}

To achieve this research, primary and secondary sources were used. Total of (100) questionnaire were handed out, (85) were come back, with a response rate of $(85 \%)$ percent. Some of the coming back questionnaires are eliminated due to insufficient information. As a result, a totality of (77) questionnaire were specified compatible and taken up into statistical analysis. The questionnaires were handed out and collected within 15 working days. A letter has been copied with the questionnaire explaining the purpose of the research project and reassuring participant of the privacy of their answers, From the theme's point of view, it is worth having respondents who are in leading positions because they may have greater influence upon the creation and increase of values of the companies, and are capable of implementing changes within organization. It is remarkable to reference that the questionnaire for this study had translated into Arabic.

\subsection{Research Philosophy and Methods}

Since there have been rapidly increasing interest on BSC in third world and developing countries and Sudan is one of these countries this have encouraged the researcher to adopt this research. Since the main objective of this research is examine the impact of balanced scorecard on private telecommunication organizations in Sudan. The researcher supposed that this philosophy is fitting and will help in reaching objectivity. The researcher is adopted both descriptive and quantitative method for analysis. Firstly, the SPSS package was used in order to set data into a system. Reliability analysis was organized and carried out on all questions in the survey instrument so as to obtain a better understand of the relationship among research variable, Spearman's correlation analysis was carried out to weigh up the relationship between balanced scorecard and performance. The mean is adopted to measure the average answer of respondent and the standard deviation is adapted to measure variation. The scale adopted in the survey was a five- point Likert scale. Cronbach Alpha coefficient was adopted also so as to measure the reliability and internal consistency of the questionnaire.

\subsection{Reliability and Validity}

Before making formal application of statistical tools, the estimation of reliability and internal consistency of questionnaire is absolutely necessary, (Hair, et al, 2007) define the validity as "the degree to which a measure accurately represent what it is supposed to" so as to be sure that the questionnaire is obvious, identifiable, measuring what intend to measured and leaving little room for ambiguity the questionnaire was submitted to four professional and college in the field of the study. Reliability differs from validity in that it relates not to what should be measure, but instead to how to be measured. Reliability is defined as the extent to which variable or set of variables is consistent in what it, Cronbach Alpha reliability test is conducted. The researcher checked the Reliabilities and they are between (.79) and (.90), which is acceptable value). Cronbach alpha of the all scales used in this study is (.82) this point out that the scales of this study is high reliable for data analysis.

\section{Data Analysis}

\subsection{Respondent Profile}

$89.7 \%$ of those who reply for the questionnaire were male and $10.3 \%$ were female. Greater part of the respondent $(75 \%)$ hold B.SC degree, (15\%) possess M.sc degree, and (3.3\%) diploma certificate and (6.7) possess $\mathrm{PhD}$, and $(21.7 \%)$ of the of those who reply for the questionnaire have 10-14 years experiences, 35.7\% have 5-9 years experience. (86.7\%) of the respondent were married. In Job title, $60.7 \%$ were assistant manager, $16.3 \%$ General manager \&above and $23 \%$ were senior manager.

\subsection{Hypotheses Test}

Spearman's correlation was used to measure the relation between BSC and organizations performance. Because the correlation coefficient is extremely fruitful method epitomize the relation between two variables with a single number that falls between $(-1$ and +1$)$. (Ayesha (2012), confirmed that -1.0 point to a perfect negative correlation, 0.0 point to no correlation, and +1.0 point to a positive correlation. The result of correlation analysis (see table 1 ) articulate that there is strong positive significant relation between BSC and organizational performance in telecommunication companies in Sudan (correlation .858 at .01 level). Also it is found that there is strong positive relation between financial perspective and organization performance of telecommunication companies sector in Sudan (correlation .563 at .01 level). It can be observed that the correlation of customer perspective in the BCS model is. 664 and the significant level is 01 this indicates that customer perspective in the BCS model is positively correlated with organization performance in the telecommunication companies in Sudan. It is also evident from table 1. that internal processes perspective in the BCS model is positively correlate with organization performance of telecommunication companies in Sudan.(correlation .768 at 01 level).it is also found that there is strong positive relation between learning \& growth and organization performance of 
telecommunication companies in Sudan (correlation .663 at .01 level) the results tells a significant positive relationship between organization performances of telecommunication companies Sudan. Table 1 delineates the mean score and standard deviation of the four variables. All the factors are having score more than 3.6 though the value of the deviation is less than (1.00) which mean that the concentration of the answers and lack of dispersion. (See table 2). Therefore, the correlation analysis confirmed that all the four hypotheses were accepted. And the finding of the research shows that all balanced scorecard perspective had a significant relation with organizational performance. This result strongly supports the research which indicates to the value of balanced scorecard to organization performance.

Table 1. The correlation between BSC and organizational performance

\begin{tabular}{|c|c|c|c|c|c|c|c|}
\hline & & $\begin{array}{l}\text { Balanced- } \\
\text { scorecard }\end{array}$ & $\begin{array}{c}\text { Financial } \\
\text { Perspective }\end{array}$ & $\begin{array}{l}\text { Customer } \\
\text { Perspective }\end{array}$ & $\begin{array}{c}\text { Internal } \\
\text { Perspective }\end{array}$ & $\begin{array}{l}\text { Learning \& growth } \\
\text { Perspective }\end{array}$ & $\begin{array}{c}\text { Organizational } \\
\text { Performance }\end{array}$ \\
\hline \multirow[t]{2}{*}{ Spearman's } & $\begin{array}{l}\text { correlation } \\
\text { coefficient }\end{array}$ & 1.000 & $.823 * *$ & $.724 * *$ & $.678 * *$ & $.809 * *$ & $.858 * *$ \\
\hline & Sig. (1-tailed) & & .000 & .000 & .000 & .000 & .000 \\
\hline \multirow[t]{2}{*}{$\begin{array}{l}\text { financial } \\
\text { perspective }\end{array}$} & $\begin{array}{l}\text { correlation } \\
\text { coefficient }\end{array}$ & $.808 * *$ & 1.000 & $.482 *$ & $651 * *$ & .674 & $.563^{* *}$ \\
\hline & Sig. (1- tailed) & .000 & & .015 & .000 & .000 & .008 \\
\hline \multirow[t]{2}{*}{$\begin{array}{l}\text { customer } \\
\text { perspective }\end{array}$} & $\begin{array}{l}\text { correlation } \\
\text { coefficient }\end{array}$ & $.764 * *$ & $.631 * *$ & 1.000 & $.324 *$ & $.706 * *$ & $.644 * *$ \\
\hline & Sig. (1- tailed) & .000 & .000 & & .064 & .000 & .000 \\
\hline \multirow[t]{2}{*}{$\begin{array}{l}\text { internal } \\
\text { perspective }\end{array}$} & $\begin{array}{l}\text { correlation } \\
\text { coefficient }\end{array}$ & $.823 * *$ & .792 & $.526^{*}$ & 1.000 & $.622 * *$ & $.768 * *$ \\
\hline & Sig. (1- tailed) & .000 & .000 & .014 & & .004 & .000 \\
\hline \multirow{2}{*}{$\begin{array}{l}\text { learning \& } \\
\text { growth } \\
\text { perspective }\end{array}$} & $\begin{array}{l}\text { correlation } \\
\text { coefficient }\end{array}$ & $.747 * *$ & $.489 * *$ & $.625 * *$ & $.567 * *$ & 1.000 & $.663 * *$ \\
\hline & Sig. (1- tailed) & .000 & .005 & .000 & .010 & & .000 \\
\hline \multirow[t]{2}{*}{$\begin{array}{l}\text { Organizational } \\
\text { performance }\end{array}$} & $\begin{array}{l}\text { correlation } \\
\text { coefficient }\end{array}$ & $825^{* *}$ & $.463 * *$ & $.544 * *$ & $.754 * *$ & $.708 * *$ & 1.000 \\
\hline & Sig. (1- tailed) & .000 & .009 & .007 & .000 & .000 & \\
\hline
\end{tabular}

** Significant at.01 level (1-tailed)

* Significant at .05 level (1-tailed)

Table 2. Mean \& Std. deviation of balanced scorecard

\begin{tabular}{llc}
\hline Factors & Mean & Std. Deviation \\
\hline financial perspective & 3.824 & .7202 \\
customer perspective & 3.622 & .8711 \\
internal perspective & 3.885 & .9306 \\
learning \& growth perspective & 3.607 & .8447 \\
\hline
\end{tabular}

Source survey data, 2014.

\section{Implication: The BSC in Private Sector}

This study is examined private telecommunication managers' point of view and knowledge on the impact of using the BSC on performance. It was directed by various questions developed in the questionnaire since there are few studies in Sudan and in particular in private telecommunication companies dealing with the use and the 
impact of BSC but the managers within BSC-using private sector organizations supposed it as a valuable performance measurement and management tool. Three implications have been emerged from his study.

1) Organizational strategy should clearly communicate to private sector managers so as to increase their consciousness of the BSC performance management potential.

2) Managers and those who dealing with BSC should look for to learn from, and benchmark against other private sector organization that have developed effective BSC framework.

3) Emphasize the necessity of applying the BSC in private telecommunication companies in Sudan as strategic tool to measure and advance the performance and rationalize the decision making.

\section{Limitation and Direction for Future Research}

The BSC is an instrument which systematically expands the measurement areas traditionally involve accounting and the potential for BSC in supporting the performance management aims of private sector organization is well recognized in the literature and the major reason to implement the BSC is to improve performance. Although there are encouraged result, this research still have un inescapable limitation, the most obvious limitation of the present study is the generalizability of the study, this study has been carried out in private telecommunication companies and the researcher believed that in Sudan each organization's BSC is unique, so care must be taken in generalizing our finding. The finding of this study point out to several avenues for future research in this area and according to above research processes some suggestions are state for future research and they are summed up as follows.

1) A future research in this field could be carried out to examine the link between strategic planning, communication of strategy, and effective use of BSC in private sector.

2) As this research work carried out in private sector organizations, an empirical research could be carried out to explore the impact of the BSC on public sector organizations.

3) Since this study depends only on questionnaire as means of data collecting and the questions contained in the questionnaire are plentiful this study recommend that future researchers should be carried out using the questionnaire and interview face to face to get an immediately explanations from interviewees when it is necessary.

\section{Acknowledgements}

This research project could not have been possible without the help of many people, so I would like to offer my most sincere thanks to all who supported me and without their love I would not be what am I. My mother who inspires me with her daily supplication. My deepest gratitude is also due to my patient good humored and affectionate wife and my daughters from whom I get the oxygen for my best energy.

\section{References}

Ali, S., Hosein, R., \& Mahduih, J. (2011). An investigation into Necessary Prerequisites for Implementation of Balanced scorecard Interdisciplinary. Journal of Contemporary Research in Business, 3(6).

Ayesha, F., \& Zareen, H. (2011). Balanced scorecard Perspective on Change and Performance: study of Selected Indian Companies. Procedia Social and Behavioral science, 24(2011), 754-768. http://dx.doi.org/10.1016/j.sbspro.2011.043

Butler, A., Letza, S. T., \& Nealla, B. (1997). Long Range Planning, 30(2), 245-253. http://dx.doi.org/10.1016/S0024-6301(96)00116-1

Carlottadel, S., Rebecca, L., Emanuele, P., \& Silvia, G. (2012). Assessing Global Performance in Universities: An application of Balanced scorecard. Procedia social Behavioral science, 46(2012), 4793-4797.

Fawazi, A., David, H., \& Manzurul, A. (2011). Balanced scorecard Implementation in Jordan: An initial Analysis. International Journal of Electronic Business Management, 9(3), 196-210.

Flapper, S. D., Fortuin, L., \& Stoop, P. P. (1996). Toward Consistent Performance Measure System. International Journal of Operations and Production Management, 16(7), 27-37. http://dx.doi.org/10.1108/01443579610119144

Gaafar, M. A. (2013). The impact of strategic planning on private sector organization in Sudan: An empirical research. International Journal of Business and Management, $8(10)$. http://dx.doi.org/10.5539/ijbm.v8n10p134

Hair, J., Black, W., Babin, B., Anderson, R., \& Tatham, R. (2007). Multivariate Data Analysis (6th ed.). New 
Gersey: Pearson Education, Inc.

Hogue, Z. (2013). 20 years of Studies on the Balanced scorecard: Trend Accomplishments gaps and Opportunities for Future Research. The British Accounting Review. http://dx.doi.org/10.1016/j.bar.3013.10.003

Iaam, M. A. (2012). The possibility of Implementing Balanced scorecard in Jourdian Private Universities. International Business Research, 5(11). http://dx.doi.org/10.5539/ibr.v5n11p113

Jehads, S., \& Naseem, T. (2011). Strategic planning and Corporation Performance Relationship in Small Business firms: Evidence from a Middle East country context. International Journal of Business and Management, 6(8). http://dx.doi.org.10.5539/ijbm.v6n8p255

Kaplan, R. S., \& Winer, P. (2009). The judgment effect of management communication and a fifth balanced scorecard category on performance evaluation. Behavioral Research in accounting, 21(2), 37-56. http://dx.doi.org/10.2308/bria.2009.21.2.37

Kaplan, R. S., \& Norton, D. P. (2001), transforming the balanced scorecard from performance measurement to strategic management: part 1. Accounting Horizon, 15(1), 87-104. http://dx.doi.org/10.2308/acch.2001.15.1.87

Kaplan, R. S., \& Norton, D. P. (1993). Putting the balanced scorecard to work. Harvard Business Review, 71(51), $134-147$.

Kaplan, R. S., \& Norton, D. P. (2000). Having trouble with your strategy? Then map it. Harvard Business Review, 78(5), 167-176.

Kiran, J. F., Vinesh, R., \& Andrew, W. (2006). Lesson from implementing the balanced scorecard in small and medium size manufacturing organization technovation.

Maltz, A. C., Shenhar, A. J., \& Reilly, R. R. (2003). Beyond balanced scorecard: Refining the search for organizational success measures. Long Range planning, 36(2), 187-204. http://dx.doi.org/10.1016/S0024-6301(02)00165-6

Niven, P. (2002). Balanced scorecard step by step: maximizing performance and maintaining result. New York: John Wiley \& Sons Inc.

N $\varphi$ rreklit, H. (2000). The balanced on the balanced scorecard. Critical analysis of some of its assumption. Management Accounting Research, 11, 65-89. http://dx.doi.org/10.1006/mare.1999.0121

Paula, M., Ana, C. S., Fernando, P., \& Margarida, R. T. (2012). The balanced scorecard as an integrated model applied to the Portuguese public service: A case study in waste sector. Journal of Cleanses Production 24(2012), 20-29. http://dx.doi.org/10.1016/j.jclpr.2011.11.007

Sabrpriya, R., \& Ishita, A. R. (2011). Human Resource Manage practices and its Effect on employee job satisfaction: Study on selected small and medium sized iron \& steel firm in India. Policy and Administration Research, 1(1).

Wasatorn, S. (2012). Balanced score card practices and determination: in Thailand. Global Conference on Business and Financial Proceedings, 7(1).

\section{Copyrights}

Copyright for this article is retained by the author(s), with first publication rights granted to the journal.

This is an open-access article distributed under the terms and conditions of the Creative Commons Attribution license (http://creativecommons.org/licenses/by/3.0/). 